\title{
CHEMICAL COMPOSITIONAL ANALYSIS OF THE TAMARIX HISPIDA AERIAL PART EXTRACT OBTAINED IN ETHANOL SOLUTIONS OF DIFFERENT CONCENTRATION
}

\author{
Yerbol Iskhanov * \\ Faculty of Chemistry and Chemical Technology of Al-Farabi Kazakh National University and \\ the International Center for Chemical and Biological Sciences of the University of Karachi, \\ Almaty, Kazakhstan
}

In this article, extracts from aerial part of Tamarix hispida Wild harvested in 2016 in the Ile District of the Almaty Region during the flowering period are considered. A comparative analysis of chemical composition of extracts obtained with three extracting agents constituting ethyl alcohol solutions concentrated differently $(96 \%, 70 \%, 50 \%)$ has been made; the extracts were studied by high-performance liquid chromatography with a mass-selective detector Aligent Technologies 6400 Series Triple Quadrupole LC/MS, and were identified by mass spectra and retention times using the NIST library and Wiley LC/MS. In all the three extracts, various phthalic esters are dominant compounds, those are: Phthalicacid, octyl 2-pentylester in 96\% extract, 1,2-Benzenedicarboxylicacid, decyloctylester in 70\% extract, and Phthalicacid, hexadecyl 2-methylbutylester in 50\% extract; also, a high content of alkaloids of various groups was identified in all the extracts, for example, 4-t-Butyl-2-(4-methoxy-phenyl)-6-p-tolyl-pyridine in 96\% extract, Morphinan-4,6-diol, N-formyl-6-acetate (ester) in 70\% extract, and 7-Methylthieno [3,2-b] pyridine in 50\% extract. All of the above parameters are quite high for alkaloids in wild plants growing in Central Asia, while it should be noted that the highest alkaloid content is found in $70 \%$ alcohol extracts from aerial part of Tamarix hispida. Nitrogen-containing compounds are present in all the three extracts with the largest variety of compounds, with both nitrogen-containing dyes and alkaloids present therein. Apart from the above, a number of noteworthy metabolites containing halogens, such as Methyl (((1E)-2-(4-chlorophenyl)-3-[4-(2-furoyl)-1-piperazinyl]-3-thioxo-1-propenyl) amino) acetate (4,4\%), Alclometasone Dipropionate have been identified in the 50\% Tamarix hispida aerial part extract. Analysis of the literature data allows for a conclusion that a high content of nitrogen-containing compounds is characteristic of the Chenopodioídeae; thus, for example, plants of the Sueda genus, Halostachys and Ephedra are sources of alkaloids of the piperidine and pyrrole, pyrolidinium and morphine groups; however, the content of organic sulfur and organochlorine compounds in the Tamarix genus was not previously reported, although these classes are quite common in the Embryophytes.

Key words: Tamarix hispida, Chemical composition, HPLC-MS, Anti-inflammatory activity, Comparative analysis, Ethanol extracts

\section{INTRODUCTION}

Tamarix is ornamental shrubs or trees, mostly evergreen, with pink or white flowers. They are relatively long-lived plants that can tolerate a wide range of environmental conditions and withstand abiotic stresses, such as high temperatures, salts, and drought. Tamarix withstands salinized soils by regulating salt balance through exudation of salt excess through its leaf glands and consuming large amounts of water from underground sources $[01,02,03,04,05]$.

Plant Tamarix hispida Wild is characterized by diverse compositions of natural biologically active substances with a broad sprectrum of biological effects including antimicrobial, antifungal activity; there is information on the use of Tamarix extracts in in the therapy of syphilis and infertility; the plant is used in standard medical practice as an astringent and diuretic agent [06]. In addition, several studies have demonstrated the antioxidant and antimicrobial activity of some Tamarix species.
A number of physiologically active metabolites of various classes have been isolated from various plants of the Tamaricaceae: simple hydrocarbons and their isomers (octane, heneicosane, docosane, tricosane, heptadecane, nonadecane, hexacosane, pentacosane), terpenoids ( $\alpha$-copene, g-elemene, g-cadinene, isophytol, phytol, $\beta$-cubebene, 3- $\alpha-[3$ ",4"-dihydroxy-trans-cinnamoyl]-oxy-D-fridoolean-14-ol-28-acid, $\beta$-sitosterol, $\alpha$-cadinol, d-cadinol, $\alpha$-bisabolol) and their derivatives; fatty acids and their esters (hexanoic acid, heptanoic acid, 2-ethylhexanoic acid, methyl palmitate, hexadecanoic, octanoic, dodecanoic acids), aromatic compounds (vanilline, benzyl benzonate, benzyl cinnamate) and alcohols (tridecanol, eugenol) [07].

Compounds of various classes were isolated directly from the Tamarix hispida aerial part, such as: ursolic acid - 1, 2 methyl ester of 3ß-al-D-fridoolean-14-ene28-onic acid, 3- $\alpha-[-[3 ", 4$ "-dihydroxytrans-cinnamoyl]oxy-D-fridoolean-14-ene-28-oic acid (isotamarixene) - 3, 3-a-hydroxy-D-fridooleane-14-ene-28-oic acid - 4,

* Faculty of Chemistry and Chemical Technology of Al-Farabi Kazakh National University, 71 al-Farabi Ave., Almaty, 
3- $\alpha$-[4"-hydroxy-trans-cinnamoyloxy]-D-firdoolean-14ene-28-oic acid - 5, isorhamnetin, 3,5-dihydroxy-4',7-dimethoxyflavone, rhamnocitrin, afzelin, 5,3'- dihydroxy-7,4'-dimethoxyflavone 3-O- $\beta$-D-glucopyranoside, 4-hydroxy-3,5-O-dimethylbenzoic acid, 7,3',4'-trihydroxy-5-methoxyflavone, 3,7,4'-trihydroxy-5-methoxyflavone, 3,5,7-trihydroxy-3',4'-dimethoxyflavone, kaempferide-3-O- $\beta$-glucopyranoside [08].

It has been known that composition of plant extracts directly depends on a variety of factors, such as extraction process temperature, extraction time, plant raw material/ extracting agent ratio and, of course, the nature of the solvent or solvent system used is the main factor [09].

Depending on the tasks to be solved, a wide array of organic solvents such as hexane, chloroform or benzene is used to extract biologically active substances.

However, most organic solvents are highly toxic compounds, have a build-up effect in tissues or are carcinogens, whereby it is requireв to include additional steps for drug substance purification and additional methods for quality control of such preparations. These measures lead to an imminent increase in the cost of end product [10].

It is for this reason that the majority of vegetable extracts use ethanol/water solvent system in various proportions.

Ethanol has the following advantages:

- Ethyl alcohol is the only organic solvent whose residual amount is little if at all limited in pharmaceutical preparations (except for injectable preparations).

- Ethanol has a high extractive power.

- Ethyl alcohol possesses bactericidal and preserving property that ensures prolonged period of validity for alcohol-based preparations

- When highly-purified until it is suitable for use in medical purposes, ethanol is a fairly affordable solvent.

- Ethanol extracts alone are a finished dosage form for various BAS complexes.

With reference to the above mentioned, the authors chose ethanol as a basic solvent for obtaining an active ingredient from aerial part of Tamarix hispida.

This article performs a comparative analysis of the phytochemical composition of Tamarix ethanol extracts with different alcohol/water ratios. The goal of the research was to make a comparative analysis of the chemical composition of extracts educed from aerial part of Tamarix hispida using three solvents that are different in polarity types, with all the three systems approved for use as a basis for dosage forms. A fundamental significance of the research lies in widespread distribution of the Tamaricaceae family plants in arid zones world-wide and in a variety of studies dealing with the distribution range and dynamics of this plant species in the United States, the EU countries and the Middle East [11, 12, $13,14]$. In addition, representatives of the Tamaricaceae family contain a significant amount of biologically active substances and can become a promising medicinal raw material [15, 16, 17, 18].

It should be noted that Tamarix hispida species is the least studied in terms of chemical composition. This paper deals with the chemical composition of aerial part of Tamarix hispida mainly found in Iran, in the western part of China and in Central Asia.

\section{EXPERIMENTAL MATERIALS}

For comparison, the authors chose the following three solvent systems to obtain an extract from aerial part of Tamarix: $96 \%$ ethanol, $70 \%$ ethanol, $50 \%$ ethanol

As the main method for studying chemical composition, the authors opted for the method of high performance liquid chromatography with mass-selective detector as the most accurate and universal, which allows for identification of the widest possible spectrum of compounds.

\section{EXPERIMENTAL PROCEDURE}

All the extracts were obtained by the following procedure:

- $10 \mathrm{I}$ of solvent was added to $500 \mathrm{~g}$ of aerial part of Tamarix hispida plant species harvested and dried in accordance with the Pharmacopeia for 24-hour extraction using the Soxhlet method; subsequently, the resulting educt was concentrated in a rotary evaporator and dried until the solvent was completely removed at room temperature. In order to ensure an optimal approach to the study, the extract was analyzed by the thin layer chromatography on an Alugram Sil 60 plate in Butanol/Water/Acetic acid solvent system and to show fluorescence at $256 \mathrm{~nm}$ and $356 \mathrm{~nm}$ ranges and characteristic color staining in iodine vapor.

\section{MEASUREMENT}

As the next step, the extract was examined by high-performance liquid chromatography with mass selective detector Aligent Technologies 6400 Series Triple Quadrupole LC/MS under the following conditions: Poroshell 120 EC-C18 column (50 mm long, $3 \mathrm{~mm}$ in diameter, with the coating substance particle size of 4.0, 2.7 and $1.9 \mu \mathrm{m}$ ) was used, with $10 \%$ aqueous solution of methanol as mother solvent and $90 \%$ methanol as final solvent at the pressure of $11.5 \mathrm{mPa}$ and the temperature of $40^{\circ} \mathrm{C}$. Components were identified by mass spectra and retention times using the NIST library and Wiley LC/MS.

\section{RESULTS AND DISCUSSION}

In 96\% Tamarix hispida aerial part extract, a large number of phenolic and polyphenolic compounds such as Phthalicacidoctyl 2-pentylester (63.35\%), Pilloin (3.23\%), 3,8,12-Tri-O-acetylingol 7-phenylacetate (1.23\%), Hexestroldimethylether (1.21\%) has been found; in addition, a number of nitrogen-containing compounds and their aromatic derivatives have been identified, the following are distinguished by the highest content: $6 \mathrm{H}-\mathrm{Ben}-$ 
zo[b]naphtho[2,3-h]carbazole (6.17\%), Benzenamine, 4-methyl-N,N-bis(4-methylphenyl) (4.46\%) and 4-t-Butyl-2-(4-methoxy-phenyl)-6-p-tolyl-pyridine (3.57\%), one sulfur-containing compound Spiro(17-acetoxyandrostan-3-ol)2.2'(1',3'-dithiane) $(1.4 \%)$ has been identified in $96 \%$ extract.

From the data presented in Table 1 it can be seen that a significant amount of vegetable dyes passed into $96 \%$ extract from vegetable raw materials, in particular, 5,12-Dihydroquino [02,03-b] acridine-7,14-dione and compounds of the pyridine and pyrimidine series alkaloid class.

In $70 \%$ extract, aromatic compounds are also isolated; in particular, 1,2-Benzenedicarboxylicacid, decyloctylester $(69.25 \%)$ predominates. As well as in $96 \%$ extract, Pilloin $(2.09 \%)$ has been identified, and a high content of biologically active nitrogen-containing compounds has been detected: Neoaureothin (3.07\%), Morphinan-4,6-diol, $\mathrm{N}$-formyl-6-acetate(ester) (4.18\%), 2-Methoxy-N-methyl-4- (methylsulfanyl)-N-phenylbenzamide (5.04\%), 7-Methylthieno[3,2-b]pyridine (4.36\%).

As can be seen from data presented in Table 2, a significant amount of alkaloids, derivatives of pyridine and pyrimidine have passed into $70 \%$ extract, however, morphine derivatives have been also identified in $70 \%$ extract, and the number of vegetable dyes is lower than in $96 \%$ extract.

Also, 7-Methylthieno [03,02-b] pyridine organic sulfur compounds (4.36\%) are found in $70 \%$ extract.

As can be seen from data presented in Table 3, 50\% extract is distinct in the widest range of identified compounds. In addition to the previously detected polyaromatic, nitrogen-containing and sulfur-containing compounds, a significant amount of Methyl (((1E)-2-(4chlorophenyl)-3-[4-(2-furoyl)-1-piperazinyl]-3-thioxo-1propenyl)amino)acetate $(4.4 \%)$ related to organohalogen compounds has been identified, as well as natural dyes (5,12-Dihydroquino[2,3-b]acridine-7,14-dione).

Out of the classes enumerated above, such phthalic acid derivatives as Phthalicacid, hexadecyl 2-methylbutyl ester (52.89\%) and alkaloids 20-Ethyl-1,7,8-trihydroxy-6,16-dimethoxy-4-(methoxymethyl)aconitan-14-yl acetate (6.34\%), 7-Methylthieno[03,02-b]pyridine (2.69) also predominate, although in a smaller amount than in the above extracts.

As follows from the above data, in all the extracts under study, a high content of nitrogen-containing compounds and compounds related to the class of alcohol esters, as well as polyaromatic substances, has been found.

In all the three extracts, various phthalic acid esters are dominant compounds, they are Phthalicacid, octyl 2-pentylester $(63.35 \%)$ in 96\% extract, 1,2-Benzenedicarboxylicacid, decyloctylester $(69.25 \%)$ in $70 \%$ extract and Phthalicacid, hexadecyl 2-methylbutylester (52.89\%) in $50 \%$ extract; a high content of alkaloids of various groups has been detected in all the extracts, such as 4-t-Butyl- 2-(4-methoxy-phenyl)-6-p-tolyl-pyridine (3.57\%) in 96\% extract, Morphinan-4,6-diol, N-formyl-6-acetate (ester) $(4.18 \%)$ in $70 \%$ extract and 7-Methylthieno[03,02-b]pyridine $(2.69 \%)$ in $50 \%$ extract. All of the above parameters are high enough for alkaloids found in wild plants native to Central Asia, while it should be noted that the highest alkaloid content is observed in $70 \%$ ethanol extract of aerial part of Tamarix hispida [19, 20, 21, 22].

If considering the content of different types of organic compounds in all the three extracts in more detail, one obtains the following figures:

The content of polyaromatic hydrocarbons is $0 \%$ in $96 \%$ extract, both have they been detected in $70 \%$ extract, and only one compound 1-Methylcoronene with the content of $4.22 \%$ has been identified in $50 \%$ extract.

Oxygen-containing compounds without inclusion of nitrogen, sulfur or halogen: in $96 \%$ extract $-73.34 \%$, in $70 \%$ extract $-75.97 \%$, in $50 \%$ extract $-59.17 \%$. As is obvious, the highest content of oxygen-containing compounds is found in $70 \%$ extract, the lowest in $50 \%$, while these are mainly phthalic acid derivatives in all the extracts.

Nitrogen-containing compounds are represented in all the three extracts with the widest range of compounds, whereby both nitrogen-containing dyes and alkaloids are present; let us compare the amount of nitrogen-containing compounds without sulfur and halogen in all the three extracts:

\section{- $24.36 \%$ in $96 \%$ extract \\ - $14.63 \%$ in $70 \%$ extract \\ - $17.85 \%$ in $50 \%$ extract}

In each of the extracts, the dominant ones are Benzenamine, 4-methyl-N,N-bis(4-methylphenyl) (4.46\%), $6 \mathrm{H}-B e n z o[b] n a p h t h o[02,03-h]$ carbazole $\quad(6.17 \%)$ in 96\% extract; Neoaureothin (3.07\%) Morphinan-4,6-diol, N-formyl-6-acetate (ester) (4.18\%), 5,12-Dihydroquino[02,03-b]acridine-7,14-dione (3.52\%), 20-Ethyl-1,7,8-trihydroxy-6,16-dimethoxy-4-(methoxymethyl)aconitan-14-ylacetat $(3.86 \%)$ in $70 \%$ extract; 6-Nitro-1,4-dihydropyrazolo[4,3-c]pyrazole-3-carboxylicacid (7.29\%), 5,12-Dihydroquino[2,3-b] acridine-7,14-dione (3.44\%) in 50\% extract. All the other nitrogen-containing compounds are found in relatively small amounts.

Therewith, both compounds containing only nitrogen in addition to hydrogen and carbon and those with inclusions of oxygen, sulfur or chlorine in the molecule are present; however, compounds containing only nitrogen as a heteroatom have been identified exclusively in $96 \%$ extract in the amount of $9.08 \%$, whereas the content of substances containing two heteroatoms (nitrogen and oxygen) is $15.28 \%$ in $96 \%$ extract. In $70 \%$ and $50 \%$ extracts, the fraction of oxygen-containing nitrogen compounds is $14.63 \%$ for $70 \%$ and $17.85 \%$ for $50 \%$ extracts. 
Table 1: Data of mass spectrometry of the extract with $96 \%$ ethanol

\begin{tabular}{|c|c|c|c|}
\hline Name of compound & Formula & RT & AreaSum \% \\
\hline $\begin{array}{c}\text { 8-[2-(2-Acetylaminophenyl)-2-oxoethyl]-3 isopropyl-6a,7,10b } \\
\text { trimethyldodecahydrobenzo[f]chromene-7-carboxylic acid, } \\
\text { methyl ester }\end{array}$ & C31H45NO5 & 5.96 & 0.8 \\
\hline 5,12-Dihydroquino[2,3-b]acridine-7,14-dione & $\mathrm{C} 2 \mathrm{OH} 12 \mathrm{~N} 2 \mathrm{O} 2$ & 6.43 & 2.48 \\
\hline Spiro(17-acetoxyandrostan-3-ol)2.2'(1',3'-dithiane) & $\mathrm{C} 24 \mathrm{H} 38 \mathrm{O} 3 \mathrm{~S} 2$ & 6.64 & 1.4 \\
\hline 3,8,12-Tri-O-acetylingol 7-phenylacetate & $\mathrm{C} 34 \mathrm{H} 42 \mathrm{O} 10$ & 6.99 & 1.23 \\
\hline Pilloin & $\mathrm{C} 17 \mathrm{H} 14 \mathrm{O} 6$ & 7.49 & 3.23 \\
\hline 4-Amino-2-(p-tolyl)-5H-(1)benzopyrano(4,3-d)pyrimidin-5-one & $\mathrm{C} 18 \mathrm{H} 13 \mathrm{~N} 3 \mathrm{O} 2$ & 8.11 & 2.23 \\
\hline Benzenamine, 4-methyl-N,N-bis(4-methylphenyl)- & $\mathrm{C} 21 \mathrm{H} 21 \mathrm{~N}$ & 8.40 & 4.46 \\
\hline Benzenamine, 3-methyl-N,N-bis(3-methylphenyl)- & $\mathrm{C} 21 \mathrm{H} 21 \mathrm{~N}$ & 8.78 & 1.9 \\
\hline 15H-Benzo[a]naphtho[2,3-h]carbazole & $\mathrm{C} 24 \mathrm{H} 15 \mathrm{~N}$ & 8.92 & 0.88 \\
\hline 6H-Benzo[b]naphtho[2,3-h]carbazole & $\mathrm{C} 24 \mathrm{H} 15 \mathrm{~N}$ & 9.36 & 6.17 \\
\hline 4-t-Butyl-2-(4-methoxy-phenyl)-6-p-tolyl-pyridine & $\mathrm{C} 23 \mathrm{H} 25 \mathrm{NO}$ & 10.03 & 3.57 \\
\hline Pyrrole, 2-(2-naphthyl)-3,5-diphenyl- & $\mathrm{C} 26 \mathrm{H} 19 \mathrm{~N}$ & 10.76 & 1.87 \\
\hline Hexestroldimethylether & $\mathrm{C} 2 \mathrm{OH} 26 \mathrm{O} 2$ & 11.64 & 1.21 \\
\hline $\begin{array}{l}\text { 1-(3-Furyl)-4b,7,7,9b,11a-pentamethyl-3,8-dioxohexadecahydroo- } \\
\text { xireno[2,3-d]oxireno[2',3':7,8]naphtho[2,1-f]isochromen-5-yl acetate }\end{array}$ & $\mathrm{C} 28 \mathrm{H} 34 \mathrm{O} 8$ & 11.86 & 3.65 \\
\hline $\begin{array}{c}\text { 2,4,6-Decatrienoic acid, 1a,2,5,5a,6,9,10,10a-octahydro-5,5a-dihy- } \\
\text { droxy-4-(hydroxymethyl)-1,1,7,9-tetramethyl-11-oxo-1H-2,8a-meth- } \\
\text { anocyclopenta[a]cyclopropa[e]cyclodecen-6-yl ester, } \\
{[1 \mathrm{aR}-(1 \mathrm{a} \alpha, 2 \alpha, 5 \beta, 5 \mathrm{a} \beta, 6 \beta, 8 \mathrm{a} \alpha, 9 \alpha, 10 \mathrm{a} \alpha)]}\end{array}$ & $\mathrm{C} 30 \mathrm{H} 40 \mathrm{O} 6$ & 12.81 & 0.67 \\
\hline Phthalic acid, octyl 2-pentyl ester & $\mathrm{C} 21 \mathrm{H} 32 \mathrm{O} 4$ & 13.85 & 63.35 \\
\hline
\end{tabular}


Table 2: Data of mass spectrometry of the extract with $70 \%$ ethanol

\begin{tabular}{|c|c|c|c|}
\hline Name of compound & Formula & RT & AreaSum \% \\
\hline Neoaureothin & $\mathrm{C} 28 \mathrm{H} 31 \mathrm{NO} 6$ & 0.47 & 3.07 \\
\hline Morphinan-4,6-diol, N-formyl-6-acetate(ester) & $\mathrm{C} 19 \mathrm{H} 23 \mathrm{NO} 4$ & 5.84 & 4.18 \\
\hline 5,12-Dihydroquino[2,3-b]acridine-7,14-dione & $\mathrm{C} 2 \mathrm{OH} 12 \mathrm{~N} 2 \mathrm{O} 2$ & 6.42 & 3.52 \\
\hline $\begin{array}{l}\text { 20-Ethyl-1,7,8-trihydroxy-6,16-dimethoxy-4-(methoxymethyl) } \\
\text { aconitan-14-yl acetate }\end{array}$ & $\mathrm{C} 26 \mathrm{H} 41 \mathrm{NO} 8$ & 6.97 & 3.86 \\
\hline Pilloin & $\mathrm{C} 17 \mathrm{H} 14 \mathrm{O} 6$ & 7.48 & 2.09 \\
\hline 2-Methoxy-N-methyl-4-(methylsulfanyl)-N-phenylbenzamide & $\mathrm{C} 16 \mathrm{H} 17 \mathrm{NO} 2 \mathrm{~S}$ & 8.06 & 5.04 \\
\hline $\begin{array}{c}\text { 8a-(Acetyloxy)-2a-[(acetyloxy)methyl]-6b-hydroxy-3a-methoxy- } \\
\text { 1,1,5,7-tetramethyl-4-oxo-1,1a,1b,1c,2a,3,3a,4,6a,6b,7,8-do- } \\
\text { decahydro-8ah-cyclopropa[5',6']benzo[1',2':7,8]azuleno[5,6-b] } \\
\text { oxiren-8-yl acetate }\end{array}$ & $\mathrm{C} 27 \mathrm{H} 36 \mathrm{O} 10$ & 8.88 & 1.12 \\
\hline $\begin{array}{c}\text { 10-Hydroxy-1,2,6a,6b,9,9,12a-heptamethyl-4a-methoxycar- } \\
\text { bonyl-13-oxo-1,2,3,4,4a,5,6,6a,6b,7,8,8a,9,10,11,12,12a,12b, } \\
13,14 \mathrm{~b}-\text { octadecahydro-2H-picene }\end{array}$ & $\mathrm{C} 31 \mathrm{H} 48 \mathrm{O} 4$ & 9.37 & 1.86 \\
\hline 7-Methylthieno[3,2-b]pyridine & C8H7NS & 11.64 & 4.36 \\
\hline Hexestroldimethylether & $\mathrm{C} 2 \mathrm{OH} 26 \mathrm{O} 2$ & 11.86 & 0.83 \\
\hline $\begin{array}{c}\text { 2,4,6-Decatrienoic acid, 1a,2,5,5a,6,9,10,10a-octahydro-5,5a- } \\
\text { dihydroxy-4-(hydroxymethyl)-1,7,9-trimethyl-1-[[(2-methyl-1- } \\
\text { oxo-2-butenyl)oxy]methyl]-11-oxo-1H-2,8a-methanocyclopen- } \\
\text { ta[a]cyclopropa[e]cyclodecen-6-yl ester }\end{array}$ & $\mathrm{C} 35 \mathrm{H} 46 \mathrm{O} 8$ & 12.81 & 0.82 \\
\hline 1,2-Benzenedicarboxylic acid, decyloctyl ester & $\mathrm{C} 26 \mathrm{H} 42 \mathrm{O} 4$ & 13.85 & 69.25 \\
\hline
\end{tabular}


Table 3: Data of mass spectrometry of the extract with $50 \%$ ethanol

\begin{tabular}{|c|c|c|c|}
\hline Name of compound & Formula & RT & AreaSum \% \\
\hline $\begin{array}{c}\text { Methyl (((1E)-2-(4-chlorophenyl)-3-[4-(2-furoyl)-1-piperazinyl]-3-thi- } \\
\text { oxo-1-propenyl)amino)acetate }\end{array}$ & C21H22CIN3O4S & 0.47 & 4.4 \\
\hline 6-Nitro-1,4-dihydropyrazolo[4,3-c]pyrazole-3-carboxylic acid & $\mathrm{C} 5 \mathrm{H} 3 \mathrm{~N} 5 \mathrm{O} 4$ & 5.85 & 7.29 \\
\hline 5,12-Dihydroquino[2,3-b]acridine-7,14-dione & $\mathrm{C} 2 \mathrm{OH} 12 \mathrm{~N} 2 \mathrm{O} 2$ & 6.42 & 3.44 \\
\hline $\begin{array}{l}\text { 20-Ethyl-1,7,8-trihydroxy-6,16-dimethoxy-4-(methoxymethyl) } \\
\text { aconitan-14-yl acetate }\end{array}$ & $\mathrm{C} 26 \mathrm{H} 41 \mathrm{NO} 8$ & 6.97 & 6.34 \\
\hline 1-Methylcoronene & $\mathrm{C} 25 \mathrm{H} 14$ & 7.49 & 4.22 \\
\hline 2-Methoxy-N-methyl-4-(methylsulfanyl)-N-phenylbenzamide & $\mathrm{C} 16 \mathrm{H} 17 \mathrm{NO} 2 \mathrm{~S}$ & 8.07 & 7.79 \\
\hline $\begin{array}{l}\text { 1-(3-Furyl)-4b,7,7,9b,11a-pentamethyl-3,8-dioxohexadecahydroo- } \\
\text { xireno[2,3-d]oxireno[2',3':7,8]naphtho[2,1-f]isochromen-5-yl acetate }\end{array}$ & $\mathrm{C} 28 \mathrm{H} 34 \mathrm{O} 8$ & 8.89 & 1.44 \\
\hline $\begin{array}{l}\text { 7-Hydroxy-3a,6,12a-trimethyl-1-(1,4,5-trimethylhexyl)tetradecahy- } \\
\text { dro-4H-cyclopenta[a]cyclopropa[e]phenanthren-4-one }\end{array}$ & $\mathrm{C} 30 \mathrm{H} 50 \mathrm{O} 2$ & 9.37 & 3.62 \\
\hline Alclometasone Dipropionate & $\mathrm{C} 28 \mathrm{H} 37 \mathrm{ClO} 7$ & 9.73 & 1.1 \\
\hline 4-t-Butyl-2-(4-methoxy-phenyl)-6-p-tolyl-pyridine & $\mathrm{C} 23 \mathrm{H} 25 \mathrm{NO}$ & 10.10 & 0.78 \\
\hline 7-Methylthieno[3,2-b]pyridine & C8H7NS & 11.65 & 2.69 \\
\hline 1,2-Dihydromerogedunol & $\mathrm{C} 21 \mathrm{H} 30 \mathrm{O} 4$ & 11.86 & 0.55 \\
\hline $\begin{array}{c}\text { 2,4,6-Decatrienoic acid, 1a,2,5,5a,6,9,10,10a-octahydro-5,5a-dihy- } \\
\text { droxy-4-(hydroxymethyl)-1,7,9-trimethyl-1-[[(2-methyl-1-oxo-2-bute- } \\
\text { nyl)oxy]methyl]-11-oxo-1H-2,8a-methanocyclopenta[a] } \\
\text { cyclopropa[e]cyclodecen-6-yl ester }\end{array}$ & $\mathrm{C} 35 \mathrm{H} 46 \mathrm{O} 8$ & 12.82 & 0.67 \\
\hline Phthalic acid, hexadecyl 2-methylbutyl ester & $\mathrm{C} 29 \mathrm{H} 48 \mathrm{O} 4$ & 13.87 & 52.89 \\
\hline
\end{tabular}


The amount of sulfur-containing compounds in all the three extracts is comparatively small; in 96\% Tamarix hispida aerial part extract, only one substance containing sulfur in the molecular structure has been identified, namely, Spiro(17-acetoxyandrostan-3-ol) 2.2'(1',3'-dithiane) in the amount of $2.23 \%$.

In $70 \%$ Tamarix hispida aerial part extract, two sulfur-containing compounds have been identified, whereby besides sulfur, nitrogen is present in the 7-Methylthieno[3,2-b]pyridine molecule, and oxygen is found in 2-Methoxy-N-methyl-4-(methylsulfanyl)-N-phenylbenzamide; the total mass fraction of sulfur-containing compounds is $9.4 \%$.

In 50\% Tamarix hispida aerial part extract, one compound including sulfur and nitrogen has been identified, that is, 7-Methylthieno[3,2-b]pyridine, one comprising sulfur, nitrogen and oxygen - 2-Methoxy-N-methyl-4-(methylsulfanyl)-N-phenylbenzamide, and one comprising sulfur, nitrogen, oxygen and chlorine in the molecule - Methyl (((1E)-2-(4-chlorophenyl)-3-[4-(2-furoyl)-1-piperazinyl]3-thioxo-1-propenyl)amino)acetate. It should be noted that a substance comprising both sulfur, and halogen, nitrogen and oxygen has been identified only in $50 \%$ extract. The total mass fraction of sulfur-containing compounds, including halogenated ones, is $14.88 \%$ in $50 \%$ extract.

Apart from the above, a number of noteworthy metabolites containing halogens, such as Methyl (((1E)-2(4-chlorophenyl)-3-[4-(2-furoyl)-1-piperazinyl]-3-thioxo-1-propenyl)amino)acetate (4.4\%), Alclometasone Dipropionate $(1.1 \%)$ have been identified in $50 \%$ Tamarix hispida aerial part extract, the total mass fraction of organohalogen compounds in $50 \%$ extract is $5.5 \%$.

\section{BIOLOGICAL ACTIVITY}

After the chemical composition was identified, all the three extracts were sent to the Biological Department of H.E.J. Scientific Research Institute of Chemistry International Center for Chemical and Biological Sciences, University of Karachi, Pakistan, to determine the anti-inflammatory activity. The results are shown in Table 4.

Table 4: Data of anti-inflammatory activity of ethanol extracts from aerial part of Tamarix hispida

\begin{tabular}{|c|c|c|c|}
\hline \multirow{2}{*}{ № } & \multirow{2}{*}{ Type of sample } & \multicolumn{2}{|c|}{ anti-inflammatory activity } \\
\cline { 3 - 4 } & $\begin{array}{c}\text { \%Inhibition } \\
(\mu \mathrm{g} / \mathrm{mL})\end{array}$ & IC $50(\mu \mathrm{g} / \mathrm{mL})$ \\
\hline 1 & $\begin{array}{c}50 \% \text { ethanol } \\
\text { extract }\end{array}$ & 51.8 & $35.7 \pm 3.1$ \\
\hline 2 & $\begin{array}{c}70 \% \text { ethanol } \\
\text { extract }\end{array}$ & 21 & \\
\hline 3 & $\begin{array}{c}96 \% \text { ethanol } \\
\text { extract }\end{array}$ & 11 & \\
\hline
\end{tabular}

From the data presented in Table 4, it follows that only $50 \%$ ethanol extract exhibits significant anti-inflammatory activity.

\section{CONCLUSION}

The analysis of literature data allows for a conclusion that plants of the Chenopodiaceae family are characterized by a high proportional content of nitrogen-containing compounds, for example, in plants of the Sueda genus, Halostachys and Ephedra are sources of alkaloids of the piperidine and pyrrole, pyrolidinium and morphine groups; however, the content of organic sulfur and organochlorine compounds in the Tamarix genus was not previously reported, although these classes are quite common in the Embryophytes [23, 24, 25, 26, 27, 28, 29, 30, 31, 32, 33, 34].

In the studied extracts, a large number of aromatic and polyaromatic compounds have been identified; in particular, phthalic acid esters, as well as a number of organic sulfur compounds and nitrogenuous heterocycles [35, 36, 37, 38, 39].

Many of the identified compounds have been previously found in the Central Asian species of Tamarix; in particular, the sources reviewed do not mention a presence of organic sulfur and organohalogen compounds, but their presence indirectly explains the comparatively high antifungal and antibacterial activity of Tamarix hispida and especially of its ethanol extracts, namely, $70 \%$ and $50 \%$ extracts, where the content of organic sulfur and nitrogen-containing compounds is the highest.

The final determination of anti-inflammatory activity of the extracts has shown a significant activity of $50 \%$ ethanol extract from aerial part of Tamarix hispida, similarly to another representative of the family Tamarix gallica [40]. 


\section{REFERENCES}

1. Vinogradov, A.P. (1952). Osnovnye zakonomernosti $v$ raspredelenii mikrojelementov mezhdu rastenijami i sredoj, Mikrojelementy vzhizni rastenij i zhivotnyh. Moscow: ANSSSR.

2. Bezchasnjuk, E.M., Djachenko, V.V., Kucher, O.V. (2003). Process jekstragirovanija iz lekarstvennogo rastitel'nogo syr'ja. Farmakom, vol. 1, 54-56.

3. Sokolov, L.D. (1986). Rastitel'nye resursy SSSR: Cvetkovye rastenija, ih himicheskij sostav, ispol'zovanie; Semejstva Paeoniaciae-Thymelaeaceae. Leningrad: Nauka.

4. Qaiser, M. (1983). Iran. Joum. Bot, vol. 2, 21-68.

5. Venturella, G., Baum, B., Mandracchia, G. (2007). FI. Medit, vol. 17, 25-46.

6. Sharma, S.K., Parmar, V.S. (1998). Journal of Scientific and Industrial Research, vol. 57, 873-890.

7. Umbetova, A.K., Choudhary, I.M., Burasheva, G.S., Sultanova, N.A., Abilov, Z.A. (2006). Triterpenoids of genus Tamarix. Chemistry of Natural compounds, 42: 173-176. DOI 0009-3130/06/4203-0332

8. Sultanova, N.A., Makhmoor, T., Yasin A., Abilov, Z.A., Omurkanzinova, V.B., Atta-ur-Rahman, Choudhary, M.I. (2004). Isotamarixen - a new antioxidant and prolylendopeptidase - inhibiting triterpenoid from Tamarix hispida. Planta Med, vol. 70, 65-67. DOI 10.1055/s-2004-815458

9. Milovanova, L.N. (2002). Tehnologija izgotovlenij alekarstvennyh form. Rostov na Donu: Medicina.

10. Georgievskij, V.P., Dihtjarev, S.I., Gubin, Ju.I. (1999). Fitohimija v Ukraine - itogiiperspektivy. Farmakom, vol. 3, 39-43.

11. Qingqing, Z., Junhong, B., Qiang, L., Qiongqiong, L., Zhaoqin, G., Junjing, W. (2005). Spatial and Seasonal Variations of Soil Carbon and Nitrogen Content and Stock in a Tidal Salt Marsh with Tamarix chinensis. China: Wetland. DOI 10.1007/s13157015-0647-1

12. Lite, S.J., Marler, R., Paradzick, C., Shafroth, P.B., Shorrock, D., White, J.M., White, M.S. (2007). Altered stream-flow regimes and invasive plant species: the Tamarix case, Juliet C. Stromberg. Global Ecology and Biogeography, vol. 16, 381-393. DOI: 10.1111/j.1466-8238.2007.00297.x

13. Mey, E., Wilson, H., Mycock, D., Weiersbye, I.M. (2016). The salt glands of Tamarix usneoides. International Journal of Phytoremediation, vol. 19, 587595. DOI: $10.1080 / 15226514.2016 .1244163$

14. Ksouri, R., Falleh, H., Megdiche, W., Trabelsi, N., Mhamdi, B., Chaieb, K., Bakrouf, A., Magné, C., Abdelly, C. (2009). Antioxidant and antimicrobial activities of the edible medicinal halophyte Tamarix gallica L. and related polyphenolic constituents. Food Chem. Toxicol., vol. 47, 2083-2091. doi:10.1016/j. fct.2009.05.040
15. Sehrawat, A., Sultana, S. (2006). Evaluation of possible mechanisms of protective role of Tamarix gallica against DEN initiated and 2-AAF promoted hepatocarcinogenesis in male Wistar rats. Life Sci., vol. 79, 1456-1465. doi:10.1016/j.lfs.2006.04.009

16. Souliman, A.M.A., Barakat, H.H., El-Mousallamy, A.M.D., Marzouk, M.S.A., Nawwar, M.A.M. (1991). Phenolics from the bark of Tamarix gallica. Phytochemistry, vol. 30, 3763-3766.

17. Drabu, S., Chaturvedi, S., Sharma, M. (2012). Tamarix gallica-an overview. Asian. J. Pharm. Clin. Res., vol. 5, 17-19.

18. Boulaabaa, M., Snoussi, M., Saadaa, M., Mkadmini, K., Smaoui, A., Abdelly, C., Ksouri, R. (2015). Antimicrobial activities and phytochemical analysis of Tamarix gallica extracts. Industrial Crops and Products, vol. 76, 1114-1122. doi.org/10.1016/j.indcrop.2015.08.020 0926-6690

19. Boulaaba, M., Tsolmon, S., Ksouri, R., Han, J., Kawada, K., Smaoui, A., Abdelly, C., Isoda, H. (2013b). Anticancer effect of Tamarix gallica extracts on human colon cancer cells involves Erk1/2 and p38 action on G2/M cell cycle arrest. Cytotechnology, vol. 65, 927-936. DOI 10.1007/s10616-013-9564-4

20. Yang, H., Zhou, Y., Liu, H., Du, H., Ma, Z., Li, C., Zhou, L. (2009). Inhibitory activity of the extracts and fractions from six chenopodiaceous plants on plant pathogens. Nat. Prod. Res. Dev., vol. 21, 744-747.

21. Sun, L.P., Yin, Z.D., Fu, Z.S., Zheng, S.Z., Shen, X.W. (1996). The chemical constituents of Elsholtziadensa Benth. Acta Bot. Sin, vol. 38, 672-676.

22. Liu, H., Wang, J., Zhao, J., Lu, S., Wang, J., Jiang, W., Ma, Z., Zhou, L. (2009). Isoquinoline alkaloids from Macleayacordata active against plant microbial pathogens. Nat. Prod. Commun., vol. 4, 1557-1560.

23. Sun, B., Richardo-da-Silvia, J.M., Spranger, I. (1998). Critical factors of vanillin assayforcatechins and proanthocyanidins. Journal of Agriculture and Food Chemistry, vol. 46, 4267-4274.

24. Baydar, N.G., Özkan, G., Sagdiç, O. (2004). Total phenolic contents and antibacterialactivities of grapes (Vitisvinifera L.) extracts. Food Control, vol. 15, 335-339. doi:10.1016/S0956-7135(03)00083-5

25. Djeridane, A., Yousfi, M., Nadjemi, B., Boutassouna, D., Stocker, P., Vidal, N. (2006). Antioxidant activity of some Algerian medicinal plants extracts containing phenolic compounds. Food Chemistry, vol. 97, 654-660. doi:10.1016/j.foodchem.2005.04.028

26. Shual, L., Sheng-lun, D., Ruo-Yun, C., DeQuan, Yu. (2005). Triterpenoids from the stems of Myricariapaniculata. J. of Asian Natural Products Research, vol. 7, 253-257. DOI: 10.1080/10286020410001721168 
27. Razdan, T., Harwar, S., Kachroo, V., Houl, G.L. (1982). Phytolaecanol and epiacetylaleuritolic acids. Two terpenoids from Phytolaccaacinosa. Phytochemistry, vol. 21, 2339- 2342.

28. Engvil, K.C. (1986). Chlorine - containing natural compounds in higher plants. Phyrochemistry, vol. 25, 781-791.

29. Gribble, G.W. (2000). The natural production of organobromine compounds. Environ. Sci. \& Pollut. Res., vol. 7, 37-49.

30. Gribble, G.W. (2002). The handbook of environmental chemistry Vol. 3, Part Organofluorines. Berlin: Springer-Verlag.

31. Virtanen, A.I. (1962). Some Organic Sulfur Compounds in Vegetables and FodderPlants and their Significance in Human Nutrition. Angew. Chem. internat., vol. 6, 299-306.

32. Virtanen, A.I. (1965). Studies on organic sulphur compounds and other labile substances in plants. Phytochemistry, vol. 4,207-228.

33. SauWah, Ng, Chor, K.C., Yan Wo Chan, A., Wing Lai Mak, T. (2013). Simultaneous detection of 22 toxic plant alkaloids (aconitumalkaloids, solanaceoustropane alkaloids, sophora alkaloids, strychnosalkaloids and colchicine) in human urine and herbal samples usingliquid chromatography-tandem mass spectrometry. Journal of ChromatographyB, vol. 942-943, 63-69..http://dx.doi.org/10.1016/j. jchromb.2013.10.020

34. Mali, S., Borges, R.M. (2013). Phenolics, fibre, alkaloids, saponins, andcyanogenic glycosides in a seasonal cloud forest in India. Biochemical Systematics and Ecology, vol. 31, 1221-1246. doi:10.1016/ S0305-1978(03)00079-6
35. O'Hagan, D. (2000). Pyrrole, pyrrolidine, pyridine, piperidine and tropane alkaloids. Nat. Prod. Rep, vol. 17:, 435-446. DOI: 10.1039/a707613d

36. [36] Özçelik, B., Kartal, M., Orhan, I. (2011). Cytotoxicity, antiviral and antimicrobial activities of alkaloids, flavonoids, and phenolic acids. Pharmaceutical Biology, vol. 49, 396-402. DOI: 10.3109/13880209.2010.519390

37. Kyung, K.H., Fleming, H.P. (1997). Antimicrobial Activity-of Sulfur Compounds Derived from Cabbage. Journal of Food Protection, vol. 60, 67-71. doi. org/10.4315/0362-028X-60.1.67

38. Kyung, K.H., Lee, Y.C. (2001). Antimicrobial activities of sulfur compounds derived from s-alk (en) yl-l-cysteinesulfoxides in allium and brassica. Food reviews international, vol. 17, 183-198. doi.org/10.1081/FRI100000268

39. Karker, M., Tommasi, N., Smaoui, A., Abdelly, C., Ksouri, R., Braca, A. (2016). New Sulphated Flavonoids from Tamarix africana and Biological Activities of Its Polar Extract. Planta Med, vol. 82, 1374-1380. DOI http://dx.doi.org/ 10.1055/s-0042-111520

40. Chaturvedi, S, Drabu, S, Sharma, M. (2012). Anti-inflammatory and anti-analgesic activity of Tamarix gallica. Int J Pharm Pharm Sci, vol. 3, 653-658. doi. org/10.1024/0300-9831.77.1.41
Paper submitted: 05.03.2018.

Paper accepted: 30.05.2018.

This is an open access article distributed under the CC BY-NC-ND 4.0 terms and conditions. 